\title{
English Language Learning Strategies Adopted by Bachelor Level Students (A Case Study of Nepal)
}

\author{
Ramesh Prasad Adhikary \\ Tribhuwan University, Kathmandu, M.M. Campus, Nepalgunj, Nepal
}

\begin{abstract}
This research paper is an attempt to find out the difficulties faced by the students of bachelor level in Nepal in learning English language at class. In order to achieve these objectives, two research tools questionnaire for students and class observation form were prepared. Two colleges of Banke district, Nepalgunj were selected for the collection of data. Twenty-five students were selected from each college. Questionnaires were distributed to the selected students and also classes were observed focusing on the strategies and difficulties of language learning. A very divergent situation was found in the strategies of language learning. It was varied from students to students. It was found out that the maximum use of memory strategy; they were using other strategies too. It was found that students were facing with different problems in language learning.
\end{abstract}

Index Terms - language, strategy, memory, LLS, L1 and L2, classroom activities

\section{INTRODUCTION}

English Learning strategies are specific actions, behaviors, tactics or techniques used in learning a language. All language learners use language learning strategies in learning process. So, the factors like age, gender, personality, motivation, self-concept, life- experience, learning style, excitement, anxiety, etc. affect the way in which language learners use the same learning strategies or should be trained in using and developing the same strategies to become successful learners. Learning strategies are particular actions or activities employed by learner directed towards more effective and more transferable to a new situation. O'Malley and Chamot (1990) define language strategies as the special thoughts of behavior that individual use to help them, comprehend, learn or retain new information (as cited in Griffiths, 2004). For example, asking students to guess the meaning of a new word from context rather than just looking it up in the dictionary is a popular cognitive strategy.

Different scholars have defined learning strategies in different ways. Richards et al. (1999) defines learning strategy as "a way in which a learner attempts to work out the meaning and use of words, grammatical rules and other aspect of language" (p.208). Similarly, O'Malley et al. (1985) say "Language learning strategies are operations or steps used by learners that will facilitate the storage, retrieval or use of information"(as cited in Griffiths, 2004).

In a similar vein, Oxford (1999) refers to learning strategies as "specific actions, behaviors, steps or techniques that students use to improve their own progress in developing skills in a second or foreign language" (as cited in Gass \& Selinker 2008, p. 439).

In a similar way, Cohen(1998) defines Language learning strategies as " those processes which are consciously selected by learners and which may result in action taken to enhance the learning or use of a second or foreign language, through the storage, retention, recall and application of information about the language"(as cited in Gass \& Selinker, 2008, p. 439).

Cohen (1998) went on saying that such strategies include strategies for identifying the materials that needs to be learned, distinguishing it from other material if need be, grouping it from easier learning (e.g., though classroom tasks or the completion of homework assignments), and formally committing the material to memory when it does not seem to be acquired naturally (whether though rote memory Thus, learning strategies are particular actions or activities employed by learners to make their learning easier, faster, more enjoyable, more directed, more effective and more transferable to new situation. It is an extremely powerful learning tool.

\section{A. Types of Learning Strategies}

Different scholars have classified learning strategies into different types. Rubin (1981) has identified two kinds of learning strategies and three sub- types of each. They are as follows:

1. Direct Language Learning Strategy

(i) Memory Strategy

(ii) Cognitive Strategy

(iii) Compensation Strategy

2. Indirect Language Learning Strategy 
(i) Meta cognitive Strategy

(ii) Affective Strategy

(iii) Social Strategy

Oxford (1990) identified three kinds of learning strategies: asking question, co operating with others and empathizing with others. A general example of language learning strategies in each of these categorized is as follows:

Asking question

i. Asking for clarification and verification

ii. Asking for correction

Co operating with others

i. Co-operating with peers

ii. Co-operating with proficient users of target language.

Empathizing with others

i. Developing cultural understanding.

ii. Becoming aware of other's thought and feelings.

\section{B. Use of Language Learning Strategies}

Language learning strategy helps the learners to learn that language effectively and skillfully. Ellis and Sinclair (1987) suggest that learners should be helped to become aware of their learning styles and the teacher plays an instrumental role in helping the learners how to learn the second or foreign language (as cited in Gardner and Miller, 1999, p.157).

In language learning, researchers have shown that some language learners are more successful than others. If these strategies are suggested to adopt poor learners, they can improve their language learning.

These definitions imply that language learning strategies adopted by the learners are important for a language teacher. These strategies help the teacher to make lesson according to the strategies of the learners. Learners also take benefit from learning strategies as they can leave some strategies and adopt new strategies to become successful learner and learn language easily. Thus, language learning strategies are important for teachers, learners, course designers and all other related people. So, in the present study, I have chosen learning strategies of the Bachelor level students.

\section{Objectives of the Study}

The objectives of the studies were as follows:

i. To find out and analyze the strategies adopted by Bachelor level students.

ii. To suggest some pedagogical implications.

\section{Significance of the Study}

This study will help the teachers to suggest their students to use the effective learning strategies. It will help the course designer to design the course according to the strategies learners adopts. It will be helpful for the material producers and textbook writers to devise materials according to learner's style. It will be equally useful for test constructer to design test items according to the learner strategies. So also students will get benefit from it.

\section{REVIEW OF RELATED LITERATURE}

Many researchers in the world are carrying out researches on learning strategies. Students may not be aware of the strategies and their effects on their learning. It is very important to raise awareness among students on what strategies it would be effective for them to learn language.

O’Malley et. al. (1987) conducted a research on Effectiveness of Language learning strategies instruction. It was an experimental research. They assigned 75 students to one of three instructional groups where they received training in

i) Meta cognitive, cognitive and socio affective strategies

ii) Cognitive and socio affective strategies

iii) No special instruction in language learning strategies (control group)

They conducted research for listening, speaking and vocabulary acquisition skills. The first and second were experimental groups but the third group was control group. The control group did not get special instruction in language learning. Among other findings, it was discovered that for vocabulary, the control group actually scored slightly higher than the treatment groups. O'Malley (ibid) explains these unexpected findings as being due to the persistence of familiar strategies among certain students who continued to use rote respective strategies and were unwilling to adopt the strategies presented in training, especially when they knew they would be tested within only a few minutes.

Nunan (1995), as cited in Griffiths, 2004, p. 17) conducted another classroom based study which aimed to research whether learner strategy training makes a difference in terms of knowledge. He involved 60 students in a 12 week programme designed to help them reflect on their own learning, to develop their knowledge of and ability to apply leaning strategies, to assess their own progress, and to apply their language skills beyond the classroom". He concluded that his study supported the idea that language classrooms should have a dual focus, teaching both content and an awareness of language process. 
Devkota (2003) carried out research on "Learning Strategies: An Attitudinal Study" His purpose was to find out the strategies employed to learn literature.

He used questionnaire to collect data from students and structured interview to collect information from the teachers. He found that one of the causes of studentse failure is due to lack of writing practice. Moreover, after overall analysis he found that studying texts in English are geared towards examination.

Rain (2006) conducted a research to find out the learning strategies used by Maithili learners of English at Secondary level. His study was centered on how Maithili learners of English learn English as their third language. He found that the learners used very few strategies to learn English language He concluded that the teacher and students do not use communicative approach in classroom.

Chaudhary (2009) carried out a research on "Learning Strategies Used by the Class Toppers". She aimed to find out the strategies used by the class toppers of higher education to learn the English language. She used a set of questionnaire as tool for data collection. She found that meta-cognitive (rehearsal) strategies were used by class toppers of higher education to great extent. She conducted that the Class topper students have strong desire to communicate and are willing to guess meaning when they are not sure.

Although some researchers are conducted in the area of learning strategies, no research is carried out to find the learning strategies used by the bachelor level students and the way they prepare for exam. No research yet is carried out by observing learners' actual behavior. So this researcher uses both questionnaire and observation check list as my research tool. So my study will be different from any researches carried out in the department so far.

\section{METHODOLOGY}

This study adopted the following methodology:

\section{A. Source of Data}

This research used both primary and secondary source of data to achieve the objectives.

1. Primary sources

The primary sources of data for this study were the students of Bachelor level studying in Kathmandu district.

2. Secondary Sources

The researcher used related books, journals, articles, unpublished thesis, and websites for the preparation. Some of them are Ellis (1986), Gass and Selinker (2008), Cohen (1998) and Rubin (1987).

\section{B. Sampling Procedure}

Sampling procedure was the way of determining the sample from the large heterogeneous study population. For this study, I purposively selected Kathmandu district as a research area of my study. I selected two colleges of Kathmandu. The study consisted of altogether 50 students. The researcher used non random sampling procedure while selecting the colleges. Likewise, she used the similar sampling procedure to select respondents.

\section{Tools for Data Collection}

The main tool for the collection of data was a set of questionnaire and observation checklist. The questionnaire was of two types; 15 questions were close- ended and 2 questions were open ended types. Observation checklist was used to collect information about different strategies.

\section{Process of Data Collection}

To collect the primary data the following procedure was followed:

To collect primary data collection, I distributed questionnaire to the students. I observed their classes and observed their activities at canteen too. For this I took the permission of the colleges first. Then I analyzed and interpreted the collected data and presented them in different charts and diagrams.

\section{E. Limitations of the Study}

The study had the following limitations:

i. The study was limited to two colleges.

ii. It was limited to the bachelor's first year students only.

Iii. It was limited to questionnaire and observation check list tools only.

\section{ANALYSIS AND INTERPRETATION OF DATA}

The data for this study were collected using two research tools, i.e. questionnaire and observation checklist. The data has been analyzed and interpreted under the following two main headings followed by several sub- heading.

i. Analysis of the data obtained from the questionnaire of the students.

ii. Analysis of the data obtained from the observation checklist.

A. Analysis of the Data Obtained from the Questionnaire to the Students Altogether 15 Questions Was Asked to the Sampled Students. The Responses of the Students on Each Item Are Analyzed and Interpreted under Separate Title 


\section{Preparation of Subject Matter}

First question deals with student's regularity and preparation of the subject matter. For this I gave four alternatives. They are advanced preparation, looking at the lesson, thinking about topic and without any preparation. The following figure shows the result.

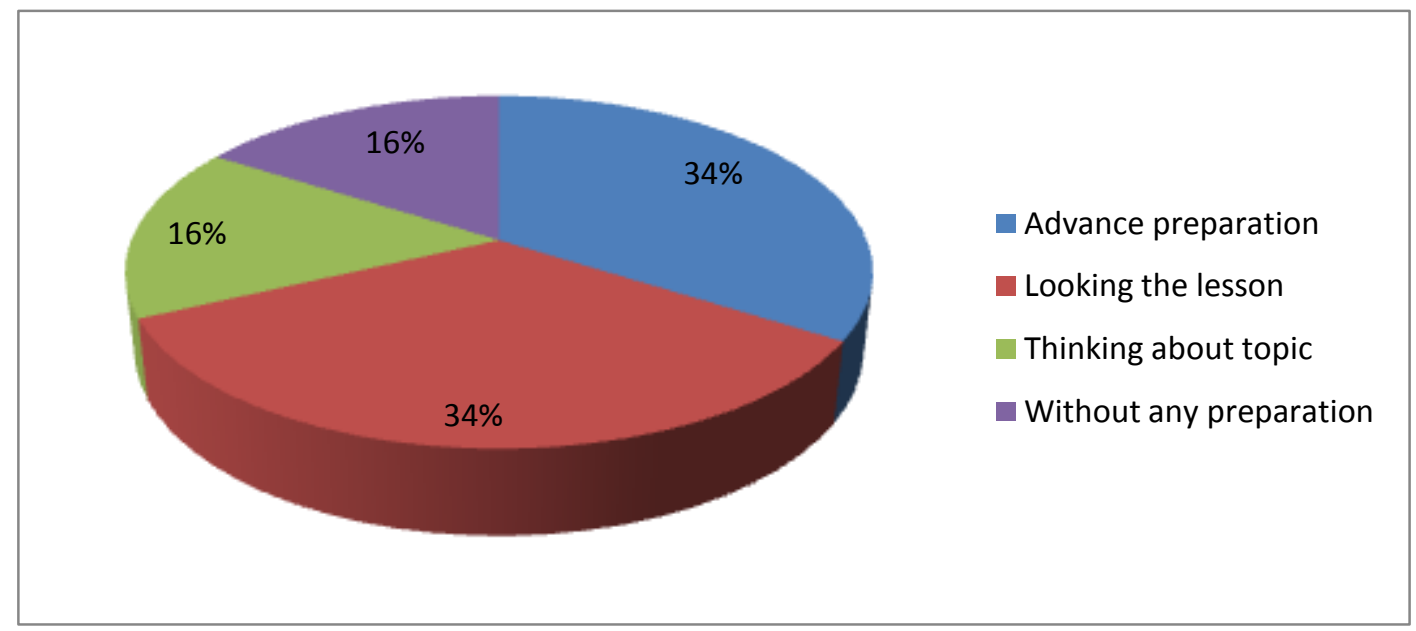

Chart No. 1 Preparation of Subject Matter

The first item was asked to identify what kind of preparation the students made before coming to school. In this item, $34 \%$ students responded that they came to class with advance preparation. On the other hand $34 \%$ of students opined that they come to school by looking at the lesson. Similarly, $16 \%$ student comes to school thinking about the topic to be learned. Sixteen percent students come to school without any preparation. A large number of students were found to have some sort of preparation before coming to school.

2. Sitting in the Classroom

Second question deals with the proper arrangement of the students in the classroom and their intention towards the study. From this question, I wanted to know how many students sit in the first bench, in the middle bench in the last bench and anywhere.

TABLE NO 1

SITTING IN THE CLASSROOM

\begin{tabular}{|c|l|c|c|}
\hline SN & \multicolumn{1}{|c|}{ Responses } & No. of Students \\
\hline 1. & In the first bench & 20 & \\
\hline 2. & In the middle bench & $40 \%$ & 17 \\
\hline 3. & In the last bench & $44 \%$ & $8 \%$ \\
\hline 4. & Anywhere & 9 & 9 \\
\hline
\end{tabular}

According to their responses, students preferred to sit on the first bench of the classroom. In this item, $40 \%$ students preferred to sit on the first bench. Only $8 \%$ students preferred to sit on the last bench whereas $34 \%$ students preferred to sit on the middle. But $18 \%$ students responded that they sit anywhere in the classroom.

3. Understanding the Meaning

While reading, the students should give due attention to reading new vocabulary used in the text. It is said that the failure to understand a single vocabulary may hinder to understand the whole sentence. Here, I tried to know how students know the meaning of words. The following figure reflects the data. 


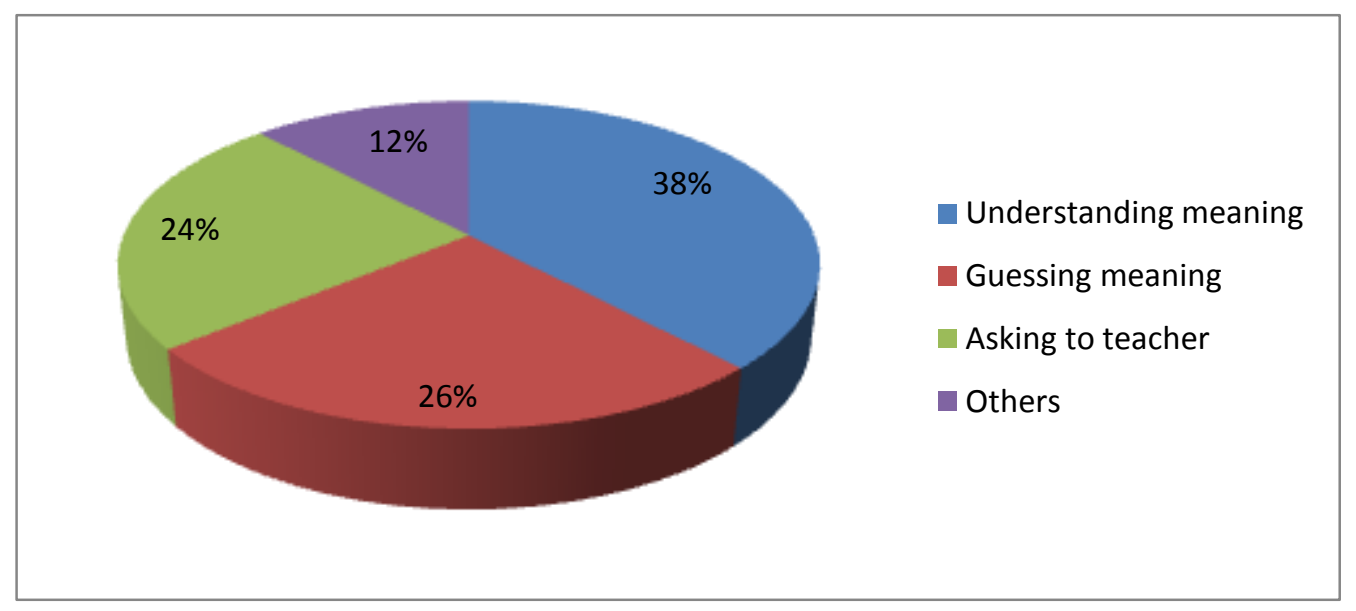

Chart No 2 Understanding the Meaning

The above chart shows that $38 \%$ students preferred to use dictionary to get the meaning of the new word. Most of them used it in their home and some students came in the class with pocket dictionary whereas $26 \%$ students responded that they preferred guessing meaning. Similarly, 24\% students responded that they preferred to ask the teacher to know the word meaning. Only12\% students chose the last option i.e. others, where they wrote that they guessed the meaning first but later consult the dictionary.

4. Learning Correct Pronunciation

From this question, I wanted to know how students pronounce the new and difficult words. I gave three alternatives to them; they are teacher's imitation, using dictionary and others.

TABLE NO. 2

LEARNING CORRECT PRONUNCIATION

\begin{tabular}{|c|l|c|c|}
\hline SN & Responses & No. of Students & Percentage \\
\hline 1. & Teacher's imitation & 28 & $56 \%$ \\
\hline 2. & Using Dictionary & 15 & $30 \%$ \\
\hline 3. & Others & 7 & $14 \%$ \\
\hline
\end{tabular}

For developing correct pronunciation, $56 \%$ students responded that they imitate the teacher speech and $30 \%$ students use dictionary to learn the correct pronunciation of new words. The third option viz others were given in the questionnaire but only $14 \%$ students selected this option.

5. Reading Comprehension

This question deals with students' behavior while reading. To get the answer, I gave four options; they are teacher's explanation, reading silently, reading loudly and others.

TABLE NO. 3

READING COMPREHENSION

\begin{tabular}{|c|l|c|c|}
\hline SN & Responses & No. of students & Percentage \\
\hline 1. & Teacher's Explanation & 16 & $32 \%$ \\
\hline 2. & Reading silently & 18 & $36 \%$ \\
\hline 3. & Reading loudly & 11 & $22 \%$ \\
\hline 4. & Others & 5 & $10 \%$ \\
\hline
\end{tabular}

For reading text and understanding it, 32\% students responded that they like the teacher's explanation. Similarly, $36 \%$ preferred silent reading and $22 \%$ preferred loud reading for understanding the text. But $10 \%$ students chose the fourth option, viz. others and wrote that s/he prefers teacher's explanation and self study for reading comprehension.

6. Speaking

From this question, I wanted to know, how students develop their speaking power. I selected four alternatives; they are teacher's imitations, games and songs, interacting with teachers and discussion. 


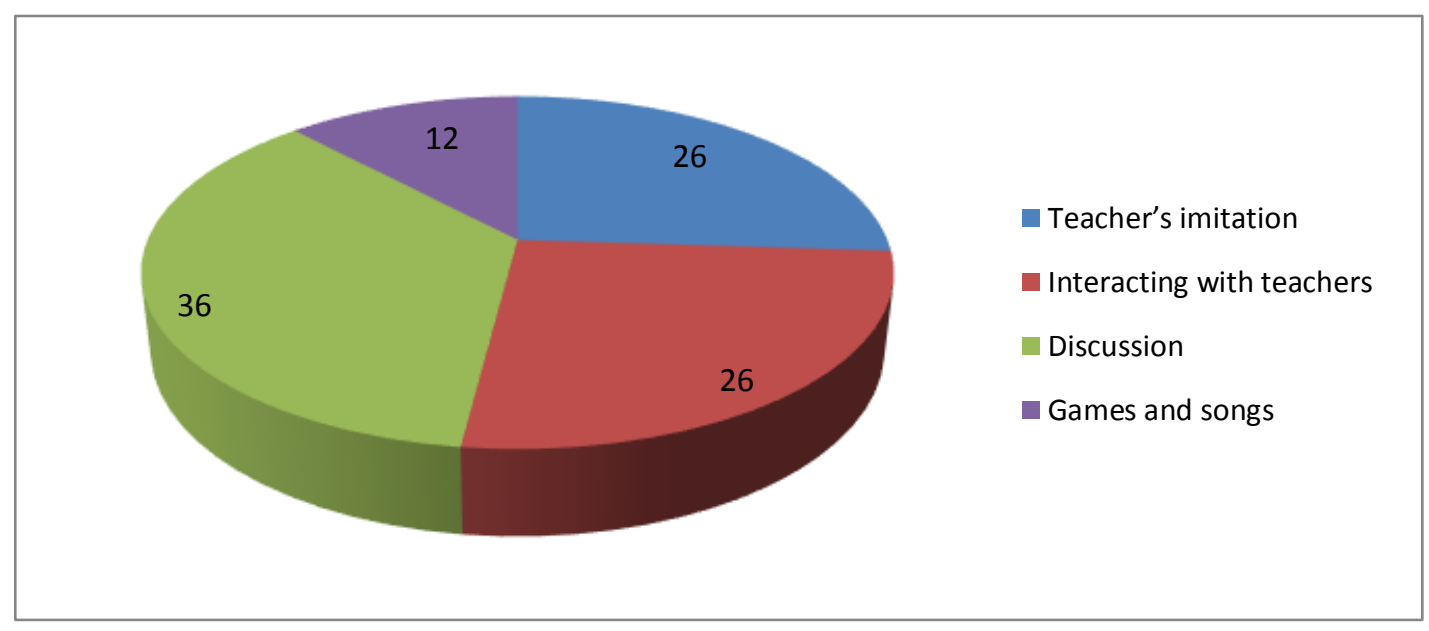

Chart No. 3 Speaking

For Speaking Practice, 26\% students responded that they speak English by imitating the teacher's speech. However, $26 \%$ students responded that they interacted with teachers for speaking practice. Similarly, $36 \%$ preferred discussion technique. But $12 \%$ students preferred songs and games for practicing speaking skill. Manly students found to be interested in discussing with others.

7. Purpose of Reading

From this question, I wanted to know the reason behind reading the text. There are many purpose of reading among them, I chose four and they understand the message, taking pleasure, preparation for examination and getting a particular message.

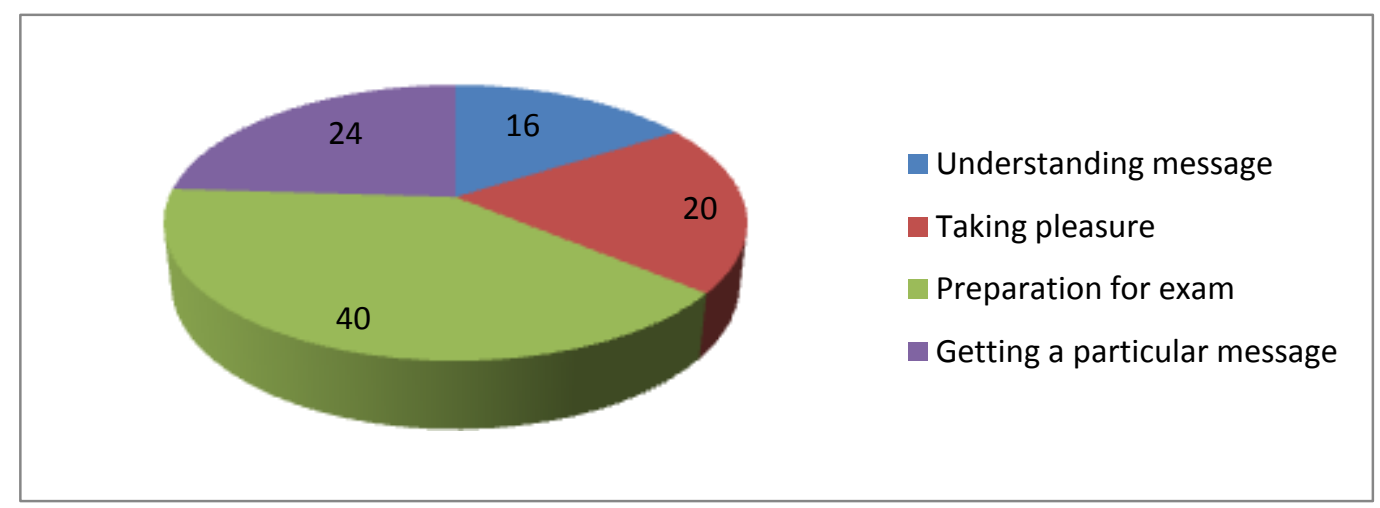

Chart No. 4 Purpose of Reading

For the purpose of reading, only $16 \%$ students responded that they read the text for understanding the general message that the text intends to give. Twenty percent responded that they read English texts for pleasure. A large number of students i.e. $40 \%$ responded that they read English text for preparation of exam. Similarly, 24\% students expressed that they read for getting specific information.

8. Literature

From the eighth item, I wanted to know the student's interest in the literary genres. That is why, I gave four literary genres as options and they are poems, stories, essays and dramas.

TABLE No. 4
Literature
\begin{tabular}{|c|l|c|c|}
\hline S.N. & Responses & No. of Students & Percentage \\
\hline 1. & Poem & 10 & $20 \%$ \\
\hline 2. & Drama & 21 & $42 \%$ \\
\hline 3. & Essay & 13 & $26 \%$ \\
\hline 4. & Stories & 6 & $12 \%$ \\
\hline
\end{tabular}

The eighth item was asked to identify which literary genre they like to read. In this item $20 \%$ students responded that they like poems. However, only $12 \%$ preferred stories and $26 \%$ preferred essays. Similarly, $42 \%$ students preferred dramas. It shows that the majority of student likes drama than other literary genres.

9. Ways of Reading Literature 
From the ninth item, I wanted to know the different techniques employed by students to read the literature. I chose four alternatives for this question and they are translation, summary from guides and guess, asking the teacher to explain and using dictionary.

TABLE NO. 5

WAYS OF READING LITERATURE

\begin{tabular}{|c|l|c|c|}
\hline \multicolumn{5}{|c|}{ WAYS OF READING LITERATURE } \\
\hline S.N. & Responses & No. of student & Percentage \\
\hline 1. & Translation & 16 & $32 \%$ \\
\hline 2. & Summary from market notes & 8 & $16 \%$ \\
\hline 3. & Asking teacher & 12 & $24 \%$ \\
\hline 4. & Using dictionary & 14 & $28 \%$ \\
\hline
\end{tabular}

According to their responses, students mainly preferred to read the translatable version of literary texts. In this item, $32 \%$ students preferred translation. Only $16 \%$ read the literary texts by reading summary from market notes. Similarly, $24 \%$ students preferred to read the texts by asking the teacher to explain it. However, $28 \%$ students preferred to read with the help of using dictionary.

10. Using Reading Materials

Tenth question deals with different reading materials. For this, I gave four options. They are guides, guess paper, text books and all of above.

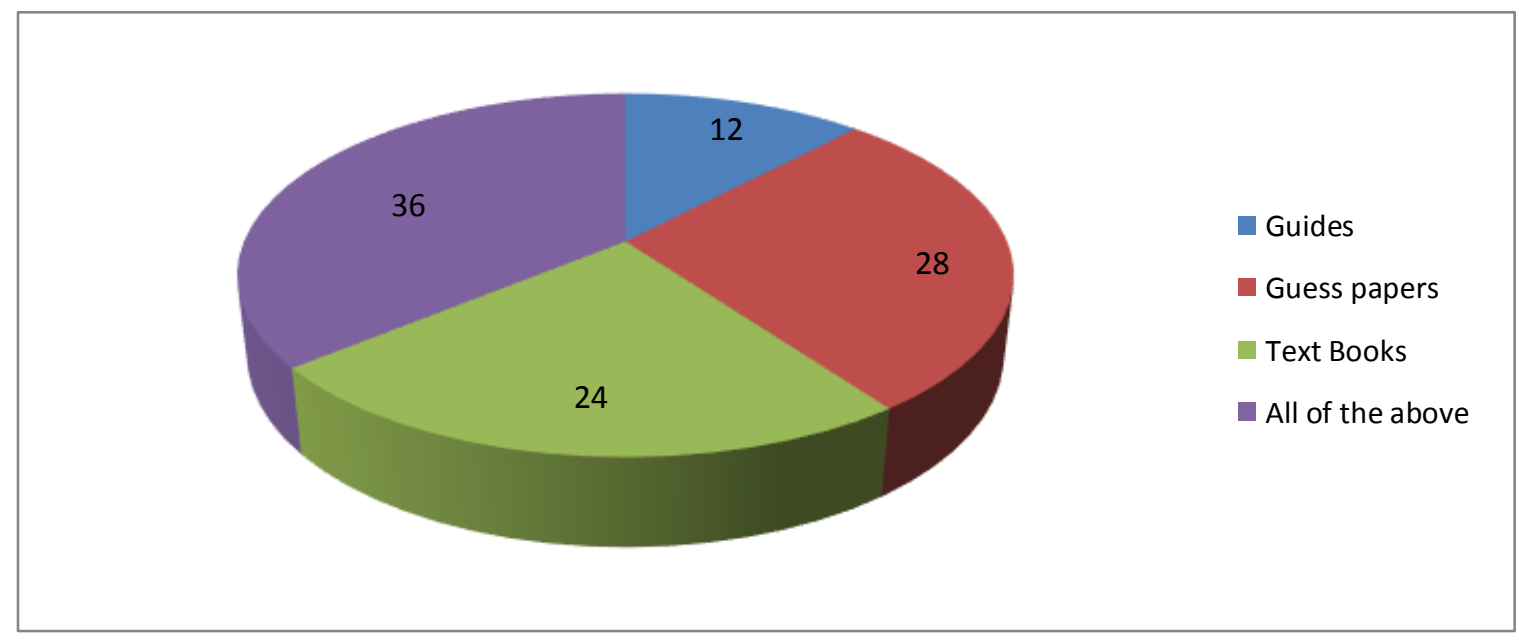

Chart No. 5 Using Reading Materials

The tenth item was asked to identify which material(s) they use for learning English. In this item, $28 \%$ students responded that they use guess papers. $24 \%$ of them responded that they used text books. Only $12 \%$ students responded that they used guide. But $36 \%$ students preferred to use all three materials i.e. textbooks, guides and guess papers. It shows that students preferred to use guides rather than textbooks and guess papers.

11. Talking in English

From this question, I wanted to know how often student's use the English language. To know their interest toward the English language, I gave four alternatives; they are only at the school compound, only in the classroom, only with teacher and with all people.

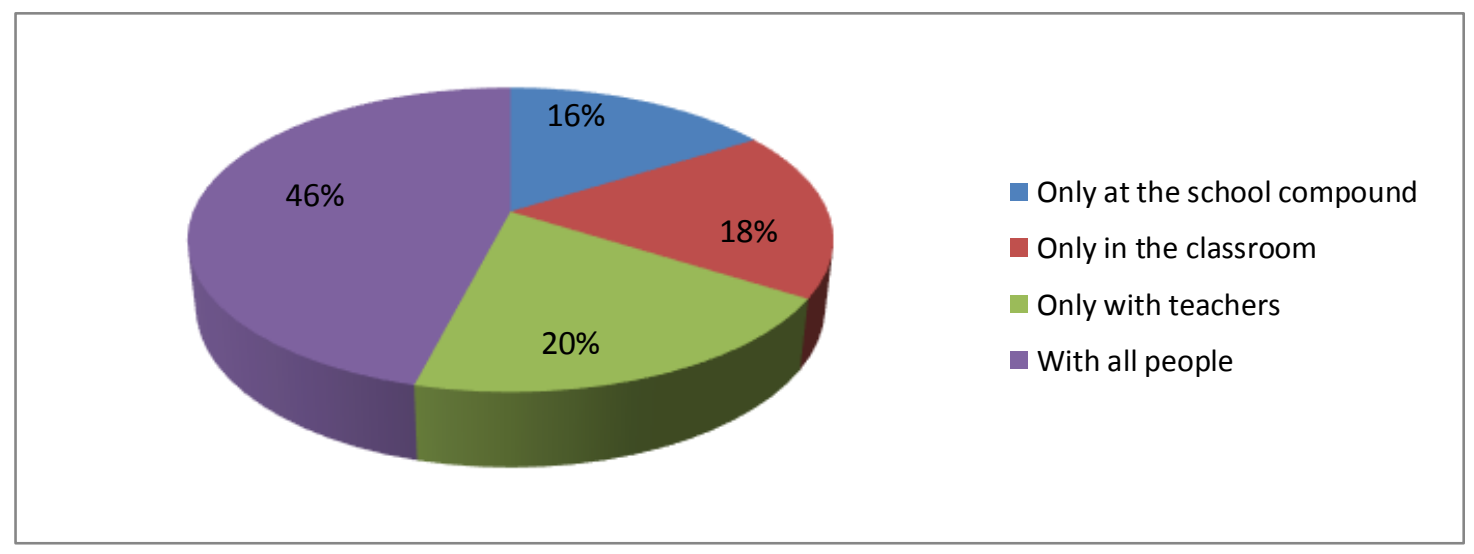

Chart No. 6 Talking in English 
Many Students (46\%) responded that they liked to speak with all the people who can talk in English. But $16 \%$ students responded that they prefer to speak in English only at the school compound and 18\% preferred to speak in English only in the classroom. Similarly, 20\% preferred to use English while talking with teachers. They were found to be interested to speak in English.

12. Taking Extra Classes

From this question, I wanted to know how often students take extra class to strengthen their study. For this question, I selected four options. They are always, never, sometimes and only before exam.

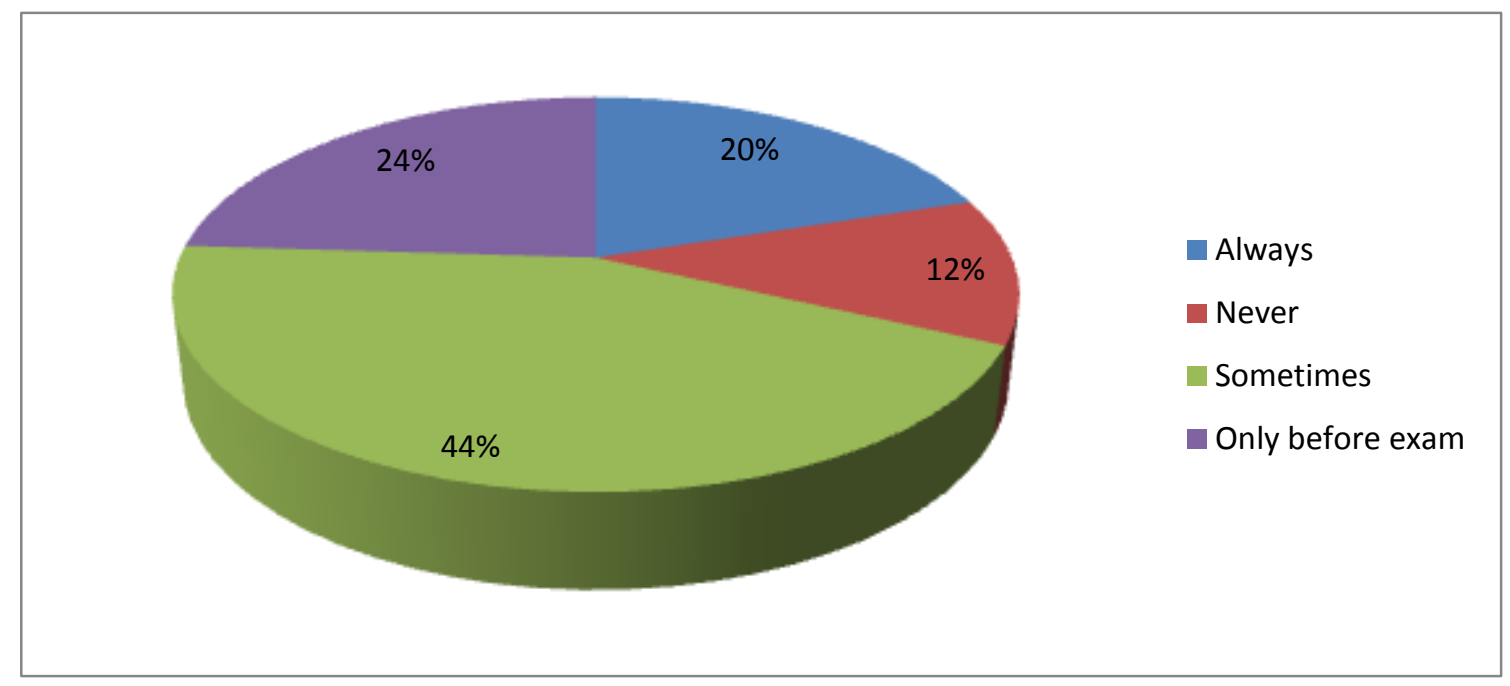

Chart No. 7 Taking Extra Classes

Regarding taking tuition, $44 \%$ responded that they take it sometimes. On the other hand, $20 \%$ responded that they always take tuition. Twenty four percent students take tuition only before exam; however, $12 \%$ responded that they never take tuition. It shows that the students prefer to take tuition sometimes.

13. Study Hours

Study plays a vital role in the learning process. Until and unless students did not labor hard, they will not get fruitful results. From the question number thirteen and fourteen, I wanted to know, how much time they generally read a day and at the time of examination. The following table presents the data.

TABLE NO. 6

STUDY HOURS

\begin{tabular}{|c|c|c|c|c|}
\hline \multirow{2}{*}{ Hours } & \multicolumn{2}{|c|}{ Usual Study } & \multicolumn{2}{c|}{ Study in Exam } \\
\cline { 2 - 5 } & No. of Students & Percentage & No of Students & Percentage \\
\hline 2 & 9 & 18 & - & - \\
\hline 3 & - & - & 5 & 10 \\
\hline 4 & 13 & 26 & 5 & 10 \\
\hline 5 & 6 & 12 & 9 & 18 \\
\hline 6 & 7 & 14 & 9 & 18 \\
\hline 7 & 2 & 4 & 7 & 14 \\
\hline 8 & 5 & 10 & 13 & 26 \\
\hline 9 & 3 & 6 & 2 & 4 \\
\hline 10 & 5 & 10 & & \\
\hline
\end{tabular}

The above table shows that students read a few hours in general but they study many hours at the time of exam. More than 63 per cent students study less than four hours per day in general but more than 75 per cent students responded that they study more than five hours per day. It was found that no student read more than eight hours in general and very a few students read $9 / 10$ hours. But many read more than $6 / 7$ hours per day at the time of exam.

14. Consulting Old Questions

From this question, I wanted to know the students' interest towards previous years' questions and their use from examination point of view. For this question, I chose four alternatives; they are always, never, sometimes and only before the exam. 


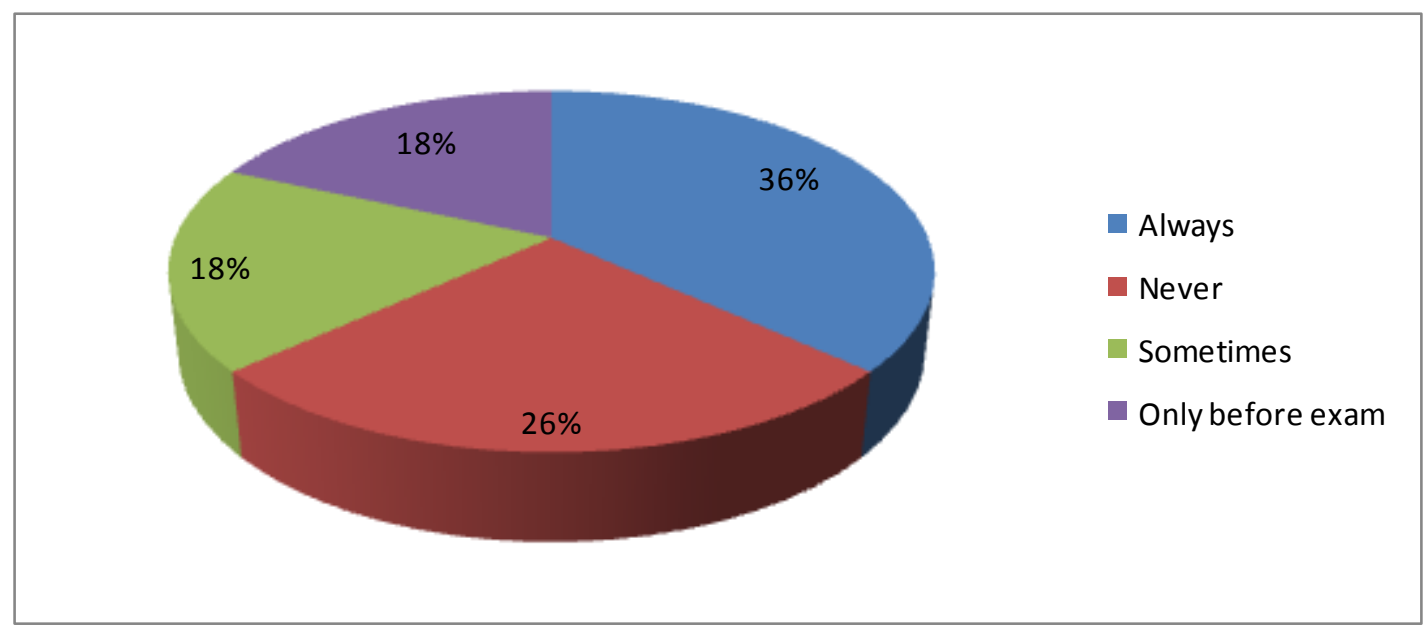

Chart No.8 Consulting Old Questions

Many students responded that they always consulted old questions and practiced them. In this item, $36 \%$ students forwarded this view. Similarly, 26\% students sometimes consulted old questions. But $18 \%$ preferred to consult old Questions only before exam. However, a very few students i.e. 18\% responded that they never consulted old questions. It was found that students prefer to practice from the old questions.

\section{B. Analysis and Interpretation of the Data Obtained from the Observation Checklist}

The researcher prepared an observation checklist as a primary tool for this research. For this, the researcher used two rating scale viz. "yes" and "no". The researcher observed the students behavior outside the classroom also at different times.

From the class observation, it was found that a good number of students used memory strategy. Highest number of students adopted this strategy. Some students used compensation strategy. Only few students used cognitive strategy. A less number of students have used both affective and social strategies.

1. Learning Activities in the Classroom

All together 50 students' activities were observed in the classroom. While observing classes, it was found that the teacher asks questions and students answer the teachers ${ }^{\text {ee }}$ questions but they rarely ask questions to their teachers.

In the observation it was found that most of the students learn the English language through rehearsal technique. They understand the subject matter with the help of teacher explanation. Teacher speaks a lot but students speak less.

Students preferred to improve their English by imitating the teachers ${ }^{\text {ee }}$ speech. It was found that students use English while talking to teacher but they mainly use Nepali while taking to their friends. Students were found to be less active than the teacher, if there was any difficulty.

2. Learning Activities outside the Classroom

Students were found to use Nepali while they are talking with friends. Students come out immediately when the teachers left the classroom. Many students were found discussing on other topics rather than the subject matter learned in the classroom.

\section{FINDINGS FROM THE ANALYSIS}

The principal aim of the present study was to find out the learning Strategies' used by students of Bachelor level. The data were collected from 50 students of two different colleges. The data were carefully presented in pie chart and tables and analyzed and interpreted to accomplish the objectives. The researcher used two tools, questionnaire and observation checklist.

Findings

On the basis of the analysis and interpretation of the collected data, the following findings were derived. The findings of the study are listed down under the following headings.

i. Findings of the data obtained from the questionnaire to the students.

ii. Findings of the data obtained from the observation checklist.

1. Findings from the Questionnaire to the Students

The researcher found a good number of students $(36 \%)$ came to school with advance preparation. It was found that majority (35\%) of students liked to sit on the first benches. It found that $38 \%$ students get meaning of new words using the dictionary. And the majority (56\%) of students developed their pronunciation by imitating the teacher's pronunciation. One third of the students $(36 \%)$ liked silent reading and teacher's explanation for reading comprehension. It was found that $38 \%$ students prefer discussion and interaction with teachers to develop speaking skill. The researcher found students prefer to read all literary genre but many of them $42 \%$ prefer drama. It was found that $32 \%$ students read 
the literary text with the help of translation. The researcher found the students use guess paper mainly, however, they also use textbooks and guides. More than $46 \%$ students like to talk using English with all those people who can speak English. It was found most of the students study at home by making their own timetable. The researcher found most of the students read English texts mainly for preparation of exam. One third of total students (36\%) consulted old questions and do practice a lot for preparing the exam.

2. Findings from Observation Checklist.

From the research, it was found that students were well motivated in the classroom. They rarely asked questions to the teacher but they were very good for answering teacher's questions. Teachers gave feedback to their students. Students followed Meta cognitive (rehearsal type of) activities to learn English in the classroom. Students did not talk about the subject matter outside the classroom. They used Nepali while talking with their friends.

\section{REFERENCES}

[1] Chaudhary, G. (2009). Learning strategies used by class toppers of higher education. An unpublished thesis of M. Ed, T.U., Kathmandu.

[2] Cohen, A.D. (1998). Strategies in learning and using second language. London and New York: Longman. Retrieved August 24, 2009 from: http://www.google.com/Language learning strategies.

[3] Devkota, H.E. (2003). Learning strategies: An attitudinal study. An unpublished thesis of M.Ed. T.U., Kathmandu.

[4] Ellis, R. (1985). Understanding second language acquisition. Oxford; Oxford University Press.

[5] Ellis, R. (1994). The study of second language acquisition. Oxford: Oxford university press.

[6] Gass,S.M. \& Selinker, L. (2008). Second Language Acquisition: An introductory Course. New York: Routledge.

[7] Griffiths, C. (2004). Language learning strategies: Theory and research, Occasional Paper1, 1-26. Retrieved August22, 2009 website: http://www.google,com/language learning strategies.

[8] Richard, J.C \& Renandya, W.A. (2010). Methodology in language teaching. Cambridge: University Press.

[9] Rain, Md.G (2006). Learning strategies used by Maithili learners of English. An unpublished thesis of M. Ed T.U. Kathmandu.

[10] Rubin, J., \& Wenden, A. (1987). Learner strategies in language learning. Britain: Cambridge University Press.

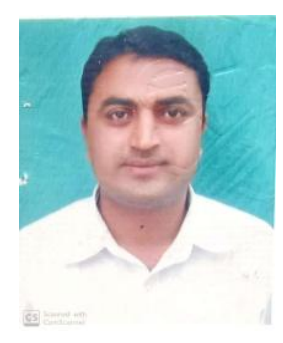

Ramesh Prasad Adhikary is an assistant professor of Tribhuwan Univeristy, Kathmandu, Nepal. He has been teaching English literature at M.M. Campus since 2007. He has completed his $\mathrm{PhD}$ in Existential philosophy and has been doing his research on English language, literature and literary theories. He has published more than 50 international articles and 18 books on various topics of English literature. 